Recyclable Self-Assembly-Supported Catalyst for ChelationAssisted Hydroacylation of an Olefin with a Primary Alcohol

Do-Won Kim, Sung-Gon Lim and Chul-Ho Jun*

Department of Chemistry

Yonsei University

Seoul 120-749, Korea (south)

e-mail : junch@yonsei.ac.kr

Supporting Information

(21 pages)

\title{
Contents
}

$\begin{array}{ll}\text { General experiments and materials } & \text { S2 }\end{array}$

Synthesis of 1a $\quad$ S3

Synthesis of $1 b \quad$ S6

Typical procedure of hydroacylation for recycling catalyst S9

${ }^{1} \mathrm{H}$, and ${ }^{13} \mathrm{C}$ NMR spectral data for new compounds $\quad \mathrm{S11}$ 
General Experiments. Flash column chromatography was performed using E. Merck 230-400 mesh silica gel. Column chromatography were monitored by analytical thin-layer chromatography (TLC) carried out on $0.25 \mathrm{~mm}$ E. Merck silica gel plates (60 F-254) using UV light as a visualizing agent and p-anisaldehyde solution, and heat and developing agent. Infrared spectra were obtained on a Nicolet Impact 400 spectrometer. Gas chromatographic analysis was performed on a Donam DS 6200 instrument with FID detector and a Hewlett-Packard HP-5 capillary column. Low-resolution mass spectra were measured on a Hewlett-Packard HP G1800A GCD system equipped with a Hewlett-Packard HP-5 capillary column. NMR spectra were record in $\mathrm{CDCl}_{3}$, and DMSO- $\mathrm{d}_{6}$ on Bruker Avance DPX 250 spectrometer $\left({ }^{1} \mathrm{H}\right.$ NMR, $250 \mathrm{MHz}:{ }^{13} \mathrm{C}$ NMR, 62.9 MHz) spectrometer, and the chemical shift was expressed in ppm relative to TMS. IR spectra were recorded on Nicolet Impact 400 spectrometer. Elemental Analysis (EA) was obtained from the Organic Chemistry Research Center, Sogang University, and National Center for InterUniversity Facilities, Seoul National University, Korea. High-resolution mass spectrometry was performed by Korea Basic Science Institute, Korea University, Seoul, Korea. For catalytic experiments, all manipulations such as weighing, decanting, charging and centrifuge, were conducted in a glove box under argon atmosphere.

Material. $\left[\mathrm{Rh}\left(\mathrm{C}_{8} \mathrm{H}_{14}\right)_{2} \mathrm{Cl}\right]_{2}$ (5) ${ }^{1}$ and 5-hexyl-2,4,6-triaminopyrimidine (2a) $)^{2}$ were prepared as described in the literature. Benzyl alcohol (6a) and 1,4-dioxane was distilled over sodium and stored over MS $4 \AA$ under nitrogen. 1,8-Dibromooctane was used after purifying by column chromatography (ethyl acetate/hexane=5/2). 1-Hexene (7a), trimethylvinylsilane (7b), ethyl diethylmalonate, urea, p-tolyldiphenylphosphine, trifluoroacetic acid, and N-bromosuccimide,

\footnotetext{
${ }^{1}$ Osborn, J. A.; Wilkinson, G. In Reagents for Transition Metal Complex and Organometallic Synthesis Angelich, R., Ed.; Wiley; New York, 1989; Vol. 28, p90-91

${ }^{2}$ Yoon, J. -H.; Park, Y. -J.; Lee, J. -H.; Yoo, J. -H.; Jun, C. -H. Org. Lett. 2005, 7, 2889.
} 
propargyl chloride were purchased from Aldrich Co., and used as received. Heptanophenone (8a), 1-(4-trifluoromethyl-phenyl)-heptan-1-one (8b), ${ }^{3}$ 1-(4-methoxy-phenyl)-heptan-1-one (8c), ${ }^{4} 1$ phenyl-3-trimethyl silanyl-propan-1-one (8d) ${ }^{5}$ were known compounds.

\section{Synthesis of 1a}<smiles>[B]NC(=O)Nc1cc(C)ccn1</smiles>

Preparation of Compound A: Ethyl diethylmalonate (1.500 g, $0.080 \mathrm{~mol})$ dissolved in DMF $(5 \mathrm{ml})$ was added dropwise to the slurry of $\mathrm{NaH}(0.383 \mathrm{~g}, 0.100 \mathrm{~mol})$ in DMF $(83 \mathrm{ml})$ at $0{ }^{\circ} \mathrm{C}$. After stirring the reaction mixture for $20 \mathrm{~min}$, propargyl chloride $(0.718 \mathrm{~g}, 0.096 \mathrm{~mol})$ in DMF (5 ml) was added dropwise to the reaction mixture in iced bath. After this reaction mixture was stirred at room temperature for $6 \mathrm{~h}$, it was treated with aq. saturated ammonium chloride solution, and extracted with ethyl acetate. Combined organic layer was washed with brine, and dried over anhydrous $\mathrm{MgSO}_{4}$. The solvents were evaporated until propargyl chloride was evaporated and the resulting brown oil was purified by flash column chromatograph (ethyl acetate / $n$-hexane $=2 / 5$ ) to afford $\mathbf{A}$ as slight brown oil (1.71 g, $95 \%$ yield). A: ${ }^{1} \mathrm{H}$ NMR (250 MHz, $\left.\mathrm{CDCl}_{3}\right) \delta$ (ppm): 4.19 (q, $\mathrm{J}=7.1 \mathrm{~Hz}, 4 \mathrm{H}), 2.81(\mathrm{~d}, \mathrm{~J}=2.7 \mathrm{~Hz}, 2 \mathrm{H}), 2.09(\mathrm{q}, \mathrm{J}=7.6 \mathrm{~Hz}, 2 \mathrm{H}), 1.99(\mathrm{t}, \mathrm{J}=2.7 \mathrm{~Hz}, 1 \mathrm{H}), 1.25(\mathrm{t}, \mathrm{J}$

\footnotetext{
3 Jun, C.-H.; Lee, D.-Y.; Kim, Y.-H.; Lee, H. Organometallics. 2001, $20,2928$.

4 Jun, C.-H.; Lee, D.-Y.; Lee, H.; Hong, J.-B. Angew. Chem. Int. Ed. 2000, 39, 3070

5 Lim, S.-G.; Jun, C.-H. Bull. Kor. Chem. Soc. 2004, 25, 1623.
} 
$=7.1 \mathrm{~Hz}, 6 \mathrm{H}), 0.87(\mathrm{t}, \mathrm{J}=7.6 \mathrm{~Hz}, 3 \mathrm{H}) .{ }^{13} \mathrm{C} \mathrm{NMR}\left(62.9 \mathrm{MHz}, \mathrm{CDCl}_{3}\right) \delta(\mathrm{ppm}): 169.9,78.6,71.0$, 61.2, 56.9, 24.6, 21.8, 13.9, 8.0. IR spectrum (KBr) 3308, 3062, 2980, 2939, 2310, 1736, 1470, $1445,1367,1270,1229,1198,1034,748 \mathrm{~cm}^{-1}$. MS (EI, $\left.70 \mathrm{eV}\right) \mathrm{m} / \mathrm{z}$ (relative intensity) 226 (8.1, $\left.\mathrm{M}^{+}\right), 197$ (100.0), 181 (57.3), 152 (61.8), 125 (76.0), 111(34.8), 97 (56.9).

Preparation of Compound 3: Compound A (4.00 g, $0.018 \mathrm{~mol})$ in DMSO (10 ml) was added dropwise to the slurry of $\mathrm{NaH}(2.83 \mathrm{~g}, 0.071 \mathrm{~mol})$ and urea $(10.62 \mathrm{~g}, 0.177 \mathrm{~mol})$ in DMSO $(50 \mathrm{ml})$ at $0{ }^{\circ} \mathrm{C}$ for $20 \mathrm{~min}$. After stirring the reaction mixture for 3 days at room temperature, it was treated with aq. saturated ammonium chloride, and extracted with ethyl acetate. Combined organic layer was washed with brine and dried over anhydrous $\mathrm{MgSO}_{4}$. The solvents were evaporated, and the resulting oil was purified by flash column chromatograph (100\% ethyl acetate) to afford 3 as a white solid (1.20 g, $35 \%$ yield). $3:{ }^{1} \mathrm{H} \mathrm{NMR}\left(250 \mathrm{MHz}, \mathrm{CDCl}_{3}\right) \delta(\mathrm{ppm})$ : 8.07 (br s, 2H), $2.83(\mathrm{~d}, \mathrm{~J}=2.6 \mathrm{~Hz}, 1 \mathrm{H}), 2.08(\mathrm{~d}, \mathrm{~J}=2.6 \mathrm{~Hz}, 1 \mathrm{H}), 2.05(\mathrm{q}, \mathrm{J}=7.4 \mathrm{~Hz}, 2 \mathrm{H}), 1.58$ (s, 2H), $0.93(\mathrm{t}, \mathrm{J}=7.4 \mathrm{~Hz}, 3 \mathrm{H}) .{ }^{13} \mathrm{C} \mathrm{NMR}\left(62.9 \mathrm{MHz}, \mathrm{CDCl}_{3}\right) \delta(\mathrm{ppm}): 172.0,149.9,78.8,74.1$, 55.4, 30.8, 26.6, 9.2. IR spectrum (KBr) 3523, 3293, 2965, 2863, 2361, 2115, 1772, 1736, 1470 , 1378, 1316, 1244, $1034 \mathrm{~cm}^{-1}$. MS (EI, $\left.70 \mathrm{eV}\right) \mathrm{m} / \mathrm{z}$ (relative intensity) $194\left(17.1, \mathrm{M}^{+}\right), 165$ (100.0), $122(62.1)$.

Preparation of Compound C: To a solution of BOC-protected 2-amino-4-picoline B (7.0 g, $0.034 \mathrm{~mol})$ in THF $(100 \mathrm{ml}), n$-BuLi $(25 \mathrm{ml}, 3 \mathrm{M})$ was added dropwise at $-78^{\circ} \mathrm{C} .1,8-$ Dibromooctane $(27.46 \mathrm{~g})$ in THF $(80 \mathrm{ml})$ was added to this reaction mixture dropwise by syringe at $0^{\circ} \mathrm{C}$. After raising the reaction mixture to room temperature, it was stirred for $4 \mathrm{~h}$, and then treated with aq. saturated ammonium chloride, and extracted with ethyl acetate. Combined organic layer was washed with brine and dried over anhydrous $\mathrm{MgSO}_{4}$. The solvent was evaporated, and the resulting oil was purified by flash column chromatography (ethyl acetate/n-heaxane $=2 / 5$ ) to give amine-protected BOC-C as brown solid (7.39 g, 55\% yield). To BOC-C (5.0 g, $0.013 \mathrm{~mol})$ 
dissolved in $\mathrm{CH}_{2} \mathrm{Cl}_{2}(20 \mathrm{ml})$, TFA (trifluoroacetic acid $4.30 \mathrm{~g}, 0.038 \mathrm{~mol}$ ) was added dropwise at 0 ${ }^{\circ} \mathrm{C}$. The reaction mixture was stirred at room temperature for $6 \mathrm{~h}$, neutralized with aq. saturated sodium bicarbonate, and extracted with ethyl acetate. Combined organic layer was washed with brine, and dried over anhydrous $\mathrm{MgSO}_{4}$. The solvent was evaporated, and the resulting brown oil was purified by flash column chromatography (ethyl acetate) to afford $\mathbf{C}$ as brown solid (3.12 g, $86 \%$ yield). C: ${ }^{1} \mathrm{H}$ NMR (250 MHz, $\left.\mathrm{CDCl}_{3}\right) \delta(\mathrm{ppm}): 7.79(\mathrm{~d}, \mathrm{~J}=5.8 \mathrm{~Hz}, 1 \mathrm{H}), 6.53(\mathrm{~d}, \mathrm{~J}=5.8$ $\mathrm{Hz}, 1 \mathrm{H}), 6.44(\mathrm{~s}, 1 \mathrm{H}), 5.95(\mathrm{br} \mathrm{s}, 2 \mathrm{H}), 3.41(\mathrm{t}, \mathrm{J}=6.8 \mathrm{~Hz}, 2 \mathrm{H}), 2.54(\mathrm{t}, \mathrm{J}=7.6 \mathrm{~Hz}, 2 \mathrm{H})$, $1.85 \sim 1.42(\mathrm{~m}, 14 \mathrm{H}) .{ }^{13} \mathrm{C}$ NMR $\left(62.9 \mathrm{MHz}, \mathrm{CDCl}_{3}\right) \delta(\mathrm{ppm}): 158.6,153.9,147.6,115.0,108.6$, 35.5, 34.3, 33.0, 30.3, 29.5, 29.3, 28.9, 28.3. IR spectrum (KBr) 3503, 2955, 2130, 1772, 1465 , 1388, 1306, $917 \mathrm{~cm}^{-1}$. MS (EI, $\left.70 \mathrm{eV}\right) \mathrm{m} / \mathrm{z}$ (relative intensity) $298\left(7.9, \mathrm{M}^{+}\right), 219(14.5), 121$ (23.7), $108(100.0)$.

Preparation of 4: To a solution of $\mathbf{C}(3.0 \mathrm{~g}, 0.010 \mathrm{~mol})$ in DMF $(30 \mathrm{ml})$ was added $\mathrm{NaN}_{3}(1.31$ $\mathrm{g}, 0.020 \mathrm{mmol})$ in DMF $(5 \mathrm{ml})$. After stirring the reaction mixture for $6 \mathrm{~h}$, it was treated with aq. sodium bicarbonate, and extracted with ethyl acetate. Combined organic layer was washed with brine, and dried over anhydrous $\mathrm{MgSO}_{4}$. The solvent was evaporated, and the resulting oil was purified by flash column chromatography (ethyl acetate) to give 4 as brown solid ( $2.52 \mathrm{~g}, 96 \%$ yield). 4: ${ }^{1} \mathrm{H}$ NMR (250 MHz, $\left.\mathrm{CDCl}_{3}\right)(\mathrm{ppm}) 7.95(\mathrm{~d}, \mathrm{~J}=5.3 \mathrm{~Hz}, 1 \mathrm{H}), 6.50(\mathrm{~d}, \mathrm{~J}=5.3 \mathrm{~Hz}, 1 \mathrm{H})$, $6.33(\mathrm{~s}, 1 \mathrm{H}), 4.35(\mathrm{br} \mathrm{s}, 2 \mathrm{H}), 3.26(\mathrm{t}, \mathrm{J}=6.89 \mathrm{~Hz}, 2 \mathrm{H}), 2.48(\mathrm{t}, \mathrm{J}=7.67 \mathrm{~Hz}, 2 \mathrm{H}), 1.75-1.30(\mathrm{~m}$, 14H). ${ }^{13} \mathrm{C}$ NMR (62.9 MHz, $\left.\mathrm{CDCl}_{3}\right) \delta(\mathrm{ppm}): 158.6,153.5,147.7,114.8,108.2,51.4,35.2,30.1$, 29.3, 29.2, 29.1, 29.0, 28.8, 26.7. IR spectrum (KBr) 3452, 3308, 2919, 2852, 2479, 2412, 2182 , 2089, 1772, 1644, $1460 \mathrm{~cm}^{-1}$. MS (EI, $\left.70 \mathrm{eV}\right) \mathrm{m} / \mathrm{z}$ (relative intensity) $231\left(\mathrm{M}^{+}, 6.2\right), 215$ (20.6), 164 (13.5), $121(100.0), 108(61.6)$.

Preparation of 1a: To a mixture of $3(0.194 \mathrm{~g}, 0.996 \mathrm{mmol})$ and $4(0.30 \mathrm{~g}, 0.829 \mathrm{mmol})$ in a mixed solvent $\left(\mathrm{THF} / \mathrm{H}_{2} \mathrm{O}=5 \mathrm{ml} / 5 \mathrm{ml}\right)$ was added $\mathrm{CuSO}_{4} \cdot 5 \mathrm{H}_{2} \mathrm{O}(10.24 \mathrm{mg}, 5 \mathrm{~mol} \%)$ and Na- 
ascorbate $(16.5 \mathrm{mg}, 10 \mathrm{~mol} \%)$, and the resulting reaction mixture was stirred at room temperature for $12 \mathrm{~h}$. After evaporating the organic solvent, unreacted starting materials were extracted with ethyl acetate $(10 \mathrm{ml})$ three times. Remaining aqueous layer was dried under reduced pressure to give a crude solid product, which was dissolved in methanol. The product in the solution was purified by column chromatography using $\mathrm{MeOH}$ as an eluent to give a pure product $1 \mathbf{1 a}(450 \mathrm{mg}$, $97 \%$ yield). 1a: ${ }^{1} \mathrm{H}$ NMR (250 MHz, DMSO-d $\left.{ }_{6}\right) \delta(\mathrm{ppm}): 11.44$ (br, 2H), 7.79 (br s, 2H), 6.32 (d, $\mathrm{J}=4.1 \mathrm{~Hz}, \quad 1 \mathrm{H}), 5.85(\mathrm{~s}, 1 \mathrm{H}), 4.23(\mathrm{t}, \mathrm{J}=6.5 \mathrm{~Hz}, 2 \mathrm{H}), 3.17(\mathrm{~s}, 2 \mathrm{H}), 2.37(\mathrm{t}, \mathrm{J}=7.2 \mathrm{~Hz}, 2 \mathrm{H}))$ 1.93-1.21 (m, 16H), $0.82(\mathrm{t}, \mathrm{J}=7.1 \mathrm{~Hz}, 3 \mathrm{H}) .{ }^{13} \mathrm{C}$ NMR (62.9 MHz, DMSO-d 6 ) $\delta(\mathrm{ppm}): 172.9$, $159.6,152.0,150.3,147.2,141.9,122.5,112.7,107.5,54.6,49.3,40.5,40.2,39.8,39.5,39.2,38.8$, 38.5, 34.6, 32.8, 31.9, 29.8, 29.7, 28.8, 28.6, 28.4, 25.8, 8.9. IR spectrum $(\mathrm{KBr}) 3462,3354,3221$, 3093, 2929, 2858, 2361, 2335, 2156, 1926, 1731, 1613, 1557, 1434, 1378, 1306, 1239, 1060, 809, $502 \mathrm{~cm}^{-1}$. Anal. Calcd for $\mathrm{C}_{23} \mathrm{H}_{33} \mathrm{~N}_{7} \mathrm{O}_{3}: \mathrm{C}, 60.64 ; \mathrm{H}, 7.30 ; \mathrm{N}, 21.52$. Found: $\mathrm{C}, 57.85 ; \mathrm{H}, 6.43 ; \mathrm{N}$, 19.00. HRMS-FAB (m/z): $[\mathrm{M}+\mathrm{H}]^{+}$calcd for $\mathrm{C}_{23} \mathrm{H}_{34} \mathrm{~N}_{7} \mathrm{O}_{3}, 456.2723$; found, 456.2733 .

\section{Synthesis of $\mathbf{1 b}$}

Compound $\mathbf{1 b}$ was prepared by the literature method with slight modification. ${ }^{2}$

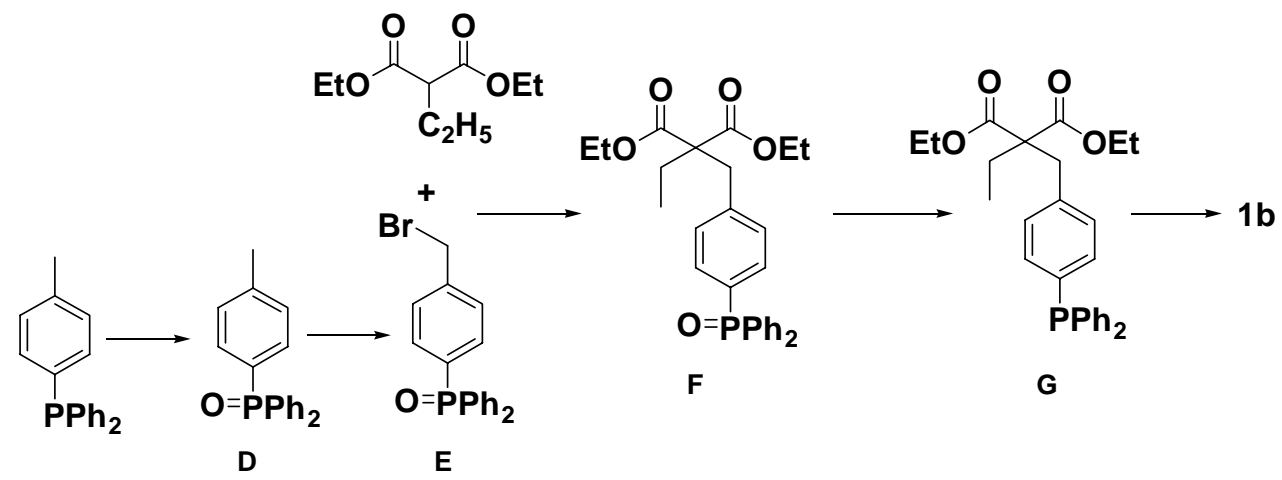


Preparation of p-tolyldiphenylphosphine oxide (D) ${ }^{6}$ : Peracetic acid in acetic acid in-situ generated from $\mathrm{H}_{2} \mathrm{O}_{2}$ /acetic anhydride $(0.27 \mathrm{~mol} / 0.42 \mathrm{~mol})$ was added dropwise to $\mathrm{p}$ tolyldiphenylphosphine (13.8 g, $0.05 \mathrm{~mol})$ dissolved in a mixed solvent of $\mathrm{CH}_{2} \mathrm{Cl}_{2}(60 \mathrm{ml})$ and acetic acid $(40 \mathrm{ml})$ on ice-water bath. After stirring the reaction mixture at room temperature for $8 \mathrm{~h}$, all solvents were evaporated. The resulting residue was neutralized with aq. sodium bicarbonate, and extracted with ethyl acetate. After evaporating the solvent, compound $\mathbf{D}$ was recrystallized from a mixed solvent of cyclohexane/acetone mixture (19:1). The resulting white crystal was washed with cold hexane, and dried in vacuo to give a pure white crystalline solid $\mathbf{D}$ (14.8 g, $92 \%$ yield). D: ${ }^{1} \mathrm{H}$ NMR $\left(250 \mathrm{MHz}, \mathrm{CDCl}_{3}\right) \delta(\mathrm{ppm}) 7.70-7.28(\mathrm{~m}, 14 \mathrm{H}), 2.40(\mathrm{~s}$, $3 \mathrm{H}) ;{ }^{13} \mathrm{C}$ NMR (62.9 MHz, $\left.\mathrm{CDCl}_{3}\right) \delta(\mathrm{ppm}) 142.7,142.6,133.8,132.4,132.3,132.2,132.2$, 132.0, 132.0, 130.1, 129.5, 129.3, 128.7, 128.5, 128.4. IR spectrum $\left(\mathrm{CDCl}_{3}\right) 3078,3059,2924$, $1602,1439,1189,907,803,733,636,543 \mathrm{~cm}^{-1}$

Preparation of F: A mixture of D (12.3 g, $0.040 \mathrm{~mol})$ and N-bromosuccinimide $(7.48 \mathrm{~g}$, $0.042 \mathrm{~mol})$ in dry $\mathrm{CCl}_{4}(40 \mathrm{ml})$ was refluxed for $8 \mathrm{~h}$. After cooling to $0{ }^{\circ} \mathrm{C}$, the resulting white solid was filtered off, and the filtrate was evaporated to dryness to afford ( $\mathrm{p}$ bromomethylphenyl)diphenylphosphine oxide (E) contaminated with (p-dibromomethylphenyl) diphenylphosphine oxide as a $4: 1$ ratio $(12.4 \mathrm{~g}$ based on $\mathbf{E})$. This mixture was used in the next step without further purification. To a slurry of $\mathrm{NaH}(0.79 \mathrm{~g}, 0.033 \mathrm{~mol})$ in DMF $(83 \mathrm{ml})$ was added ethyl diethylmalonate $(5.64 \mathrm{~g}, 0.03 \mathrm{~mol})$ dropwise at $0{ }^{\circ} \mathrm{C}$. The mixture was stirred at room temperature until the clear solution appeared. To the above homogeneous solution was added $\mathbf{E}$ (12.4 g, $0.043 \mathrm{~mol}$ of mono-brominated form) dropwise at $0{ }^{\circ} \mathrm{C}$, and the reaction mixture was stirred at $60{ }^{\circ} \mathrm{C}$ for $8 \mathrm{~h}$. After cooling to room temperature, the mixture was treated with aq. ammonium chloride, and extracted with ethyl acetate. Combined organic layer was

\footnotetext{
${ }^{6}$ Streitwieser, Jr. A.; Juaristi, E. J. Org.Chem. 1982, 47, 768.
} 
washed with brine, and dried over anhydrous $\mathrm{MgSO}_{4}$. The solvents were evaporated and the resulting residue was purified by flash column chromatography (ethyl acetate/n-hexane $=1 / 1$ ) to give $\mathbf{F}$ as a yellow oil $(8.32 \mathrm{~g}, 58 \%$ yield based on $\mathbf{E}) . \mathbf{F} .{ }^{1} \mathrm{H}$ NMR $\left(250 \mathrm{MHz}, \mathrm{CDCl}_{3}\right) \delta(\mathrm{ppm})$ 7.66-7.22 (m, 14H), $4.15(\mathrm{~m}, 4 \mathrm{H}), 3.28(\mathrm{~s}, 2 \mathrm{H}), 1.83(\mathrm{q}, \mathrm{J}=7.6 \mathrm{~Hz}, .2 \mathrm{H}), 1.21(\mathrm{t}, \mathrm{J}=7.3 \mathrm{~Hz}, 6 \mathrm{H})$, $0.91(\mathrm{t}, \mathrm{J}=7.6 \mathrm{~Hz}, 3 \mathrm{H}) .{ }^{13} \mathrm{C} \mathrm{NMR}\left(62.9 \mathrm{MHz}, \mathrm{CDCl}_{3}\right) \delta(\mathrm{ppm}) 171.2,141.1,133.5,132.8,132.7$, $132.4,132.2,131.9,130.4,130.2128 .9,128.8,128.661 .52,59.4,37.7,25.2,14.3,8.9$. IR spectrum (neat) $3025,2978,1728,1595,1437,1213,1176,1120,1030,757 \mathrm{~cm}^{-1}$.

Preparation of G: To compound F $(4.78 \mathrm{~g}, 0.01 \mathrm{~mol})$ in phenylsilane $(4.9 \mathrm{ml})$ was added trichlorosilane $(2.0 \mathrm{ml}, 0.020 \mathrm{~mol})$ dropwise at $0{ }^{\circ} \mathrm{C}$. After stirring the reaction mixture at $60{ }^{\circ} \mathrm{C}$ for $6 \mathrm{~h}$, it was diluted with ethyl ether, treated with aq. ammonium chloride, and extracted with ethyl acetate. Combined organic layer was washed with brine, and dried over anhydrous $\mathrm{MgSO}_{4}$. After evaporating the solvent, the resulting residue was purified by flash column chromatography (ethyl acetate/n-hexane $=2 / 5$ ) to give $\mathbf{G}$ as yellow oil. ( $3.83 \mathrm{~g}, 83 \%$ yield). $\mathbf{G}$ : ${ }^{1} \mathrm{H}$ NMR (250 MHz, $\left.\mathrm{CDCl}_{3}\right) \delta(\mathrm{ppm})$ 7.35-7.05 (m, 14H), $4.17(\mathrm{~m}, 4 \mathrm{H}), 3.22(\mathrm{~s}, 2 \mathrm{H}), 1.84(\mathrm{q}$, $\mathrm{J}=7.52 \mathrm{H}), 1.21(\mathrm{t}, \mathrm{J}=7.6 \mathrm{~Hz}, 6 \mathrm{H}), 0.91(\mathrm{t}, \mathrm{J}=7.6 \mathrm{~Hz}, 3 \mathrm{H}) .{ }^{13} \mathrm{C} \mathrm{NMR}\left(62.9 \mathrm{MHz}, \mathrm{CDCl}_{3}\right) \delta(\mathrm{ppm})$ $171.4,137.3,134.1,134.0,133.8,133.7,130.4,130.2,128.9,128.8,128,7,128.0,61.4,59.4$, 37.5, 25.1, 14.3, 8.9. IR spectrum (neat) 3072, 3054, 2979, 2939, 1731, 1438, 1254, 1216, 1118 , $1026,923,744 \mathrm{~cm}^{-1}$.

Preparation of 1b: Compound G $(2.31 \mathrm{~g}, 0.005 \mathrm{~mol})$ in DMF $(5 \mathrm{ml})$ was added dropwise to the slurry of $\mathrm{NaH}(0.48 \mathrm{~g}, 0.02 \mathrm{~mol})$ and urea $(3.0 \mathrm{~g}, 0.05 \mathrm{~mol})$ in DMF $(15 \mathrm{ml})$ at $0{ }^{\circ} \mathrm{C}$. The reaction mixture was stirred at $100{ }^{\circ} \mathrm{C}$ for $24 \mathrm{~h}$. After cooling to room temperature, the mixture was treated with aq. saturated ammonium chloride, and extracted with ethyl acetate. Combined organic layer was washed with brine, and dried over anhydrous $\mathrm{MgSO}_{4}$. After evaporating the solvent, the resulting white crystal was washed with hexane and dried in vacuo to give white 
crystalline solid 1b (1.74 g, yield: 81\%). 1b: ${ }^{1} \mathrm{H}$ NMR (250 MHz, DMSO-d $\left.{ }_{6}\right) \delta(\mathrm{ppm}) 11.37$ (s, 2H), 7.37-7.00 (m, 14H), $3.08(\mathrm{~s}, 2 \mathrm{H}), 1.98(\mathrm{br} \mathrm{d}, \mathrm{J}=7.3 \mathrm{~Hz}, 2 \mathrm{H}), 0.75(\mathrm{t}, \mathrm{J}=7.2 \mathrm{~Hz}, 3 \mathrm{H}) .{ }^{13} \mathrm{C}$ NMR (62.9 MHz, DMSO-d $\left.{ }_{6}\right) \delta(\mathrm{ppm}) 173.4,150.4,137.6,137.4,137.1,136.6,136.4,134.4$, 130.6, 130.5, 130.0, 129.9, 129.8, 58.8, 44.9, 32.0, 10.3. IR spectrum (KBr) 3072, 3054, 2979, 2939, 1731, 1438, 1254, 1216, 1118, 1026, 923, $744 \mathrm{~cm}^{-1}$. Anal. Calcd for $\mathrm{C}_{25} \mathrm{H}_{23} \mathrm{~N}_{2} \mathrm{O}_{3} \mathrm{P}: \mathrm{C}$, 69.76; H, 5.39; N, 6.51. Found: C, 69.82; H, 5.17; N, 6.54. HRMS-FAB (m/z): [M+H] $]^{+}$calcd for $\mathrm{C}_{25} \mathrm{H}_{23} \mathrm{~N}_{2} \mathrm{O}_{3} \mathrm{P}, 431.1524$; found, 431.1529 .

Typical procedure of hydroacylation for recycling catalyst 1a with 2a: A screwcapped pressure vial $(1 \mathrm{~mL})$ was charged with $11.7 \mathrm{mg}(0.108 \mathrm{mmol})$ of benzyl alcohol (6a), $45.4 \mathrm{mg}(0.540 \mathrm{mmol})$ of 1-hexene (7a), $3.9 \mathrm{mg}(0.0054 \mathrm{mmol})$ of $\left[\mathrm{Rh}(\mathrm{COE})_{2} \mathrm{Cl}\right]_{2}$ (5), $24.6 \mathrm{mg}$ (0.054 mmol) of 1a, $11.3 \mathrm{mg}(0.0540 \mathrm{mmol})$ of 5-hexyl-2,4,6-triaminopyrimidine (2a), $14.1 \mathrm{mg}$ (0.054 mmol) of $\mathrm{PPh}_{3}, 3.2 \mathrm{mg}(0.0324 \mathrm{mmol})$ of cyclohexylamine, $1.4 \mathrm{mg}(0.0108 \mathrm{mmol})$ of benzoic acid, and $70 \mathrm{mg}$ of 1,4-dioxane in a dry box. The reaction mixture was stirred in an oil bath that was preheated at $150{ }^{\circ} \mathrm{C}$ for $2 \mathrm{~h}$. After cooling to room temperature, $n$-pentane $(1 \mathrm{~mL})$ was added to the reaction mixture, and it was stirred, and centrifuged. The upper layer was decanted by pipette. This process was repeated three times. Solvents in combined organic solutions was evaporated, and the resulting residue was purified by column chromatography $\left(\mathrm{SiO}_{2}, n\right.$-hexane $:$ ethyl acetate $\left.=20: 1\right)$ to give $20.5 \mathrm{mg}(92 \%)$ of $\mathbf{8 a}$. To the remaining solid phase was added $11.7 \mathrm{mg}(0.108 \mathrm{mmol})$ of benzyl alcohol (6a), $45.5 \mathrm{mg}(0.540 \mathrm{mmol})$ of 1 hexene (7a), $3.9 \mathrm{mg}(0.0054 \mathrm{mmol})$ of $\left[\mathrm{Rh}(\mathrm{COE})_{2} \mathrm{Cl}\right]_{2}$ (5), $14.1 \mathrm{mg}(0.054 \mathrm{mmol})$ of $\mathrm{PPh}_{3}, 3.2$ $\mathrm{mg}(0.0324 \mathrm{mmol})$ of cyclohexylamine, $1.4 \mathrm{mg}(0.0108 \mathrm{mmol})$ of benzoic acid, and $70 \mathrm{mg}$ of 1,4-dioxane in a dry box for the next reaction. The reaction procedure was repeated, and the 
results were shown in entry 1 , Table 1.

\section{Typical procedure of hydroacylation for recycling catalyst 1a and 1b with 2a: A} screw-capped pressure vial $(1 \mathrm{~mL})$ was charged with $7.8 \mathrm{mg}(0.072 \mathrm{mmol})$ of benzyl alcohol (6a), $30.0 \mathrm{mg}(0.360 \mathrm{mmol})$ of 1-hexene (7a), $5.2 \mathrm{mg}(0.0036 \mathrm{mmol})$ of $\left[\mathrm{Rh}(\mathrm{COE})_{2} \mathrm{Cl}\right]_{2}$ (5), $23.5 \mathrm{mg}(0.050 \mathrm{mmol})$ of $1 \mathbf{a}, 24.8 \mathrm{mg}(0.0576 \mathrm{mmol})$ of $\mathbf{1 b}, 22.6 \mathrm{mg}(0.108 \mathrm{mmol})$ of 6-hexyl2,4,6-triaminopyrimidine (2a), $2.1 \mathrm{mg}(0.0216 \mathrm{mmol})$ of cyclohexylamine, $0.9 \mathrm{mg}(0.0072$ mmol) of benzoic acid. To the mixture was added a mixed solvent, phenol (20 mg) and 1,4dioxane $(25 \mathrm{mg})$. The reaction mixture was stirred at $150{ }^{\circ} \mathrm{C}$ for $2 \mathrm{~h}$. After cooling to room temperature, $n$-pentane $(1 \mathrm{~mL})$ was added to the reaction mixture, and the resulting mixture was stirred and centrifuged. The upper layer was decanted by pipette, and the lower layer was washed with $n$-pentane three times. The solvent in combined solution was evaporated and the resulting residue was purified by column chromatography $\left(\mathrm{SiO}_{2}, n\right.$-hexane : ethyl acetate $=20$ : 1) to give $14.1 \mathrm{mg}$ (95\% yield) of $\mathbf{8 a}$. To the remaining solid layer was added $7.8 \mathrm{mg}(0.072$ mmol) of benzyl alcohol (6a), $30.0 \mathrm{mg}(0.360 \mathrm{mmol})$ of 1-hexene (7a), $2.1 \mathrm{mg}(0.0216 \mathrm{mmol})$ of cyclohexylamine, and $0.9 \mathrm{mg}(0.0072 \mathrm{mmol})$ of benzoic acid for the next reaction. The reaction procedure was repeated, and the results were shown in entry 1, Table 3. 


\section{${ }^{1} \mathrm{H}$ and ${ }^{13} \mathrm{C}$ NMR spectral data for supporting information}

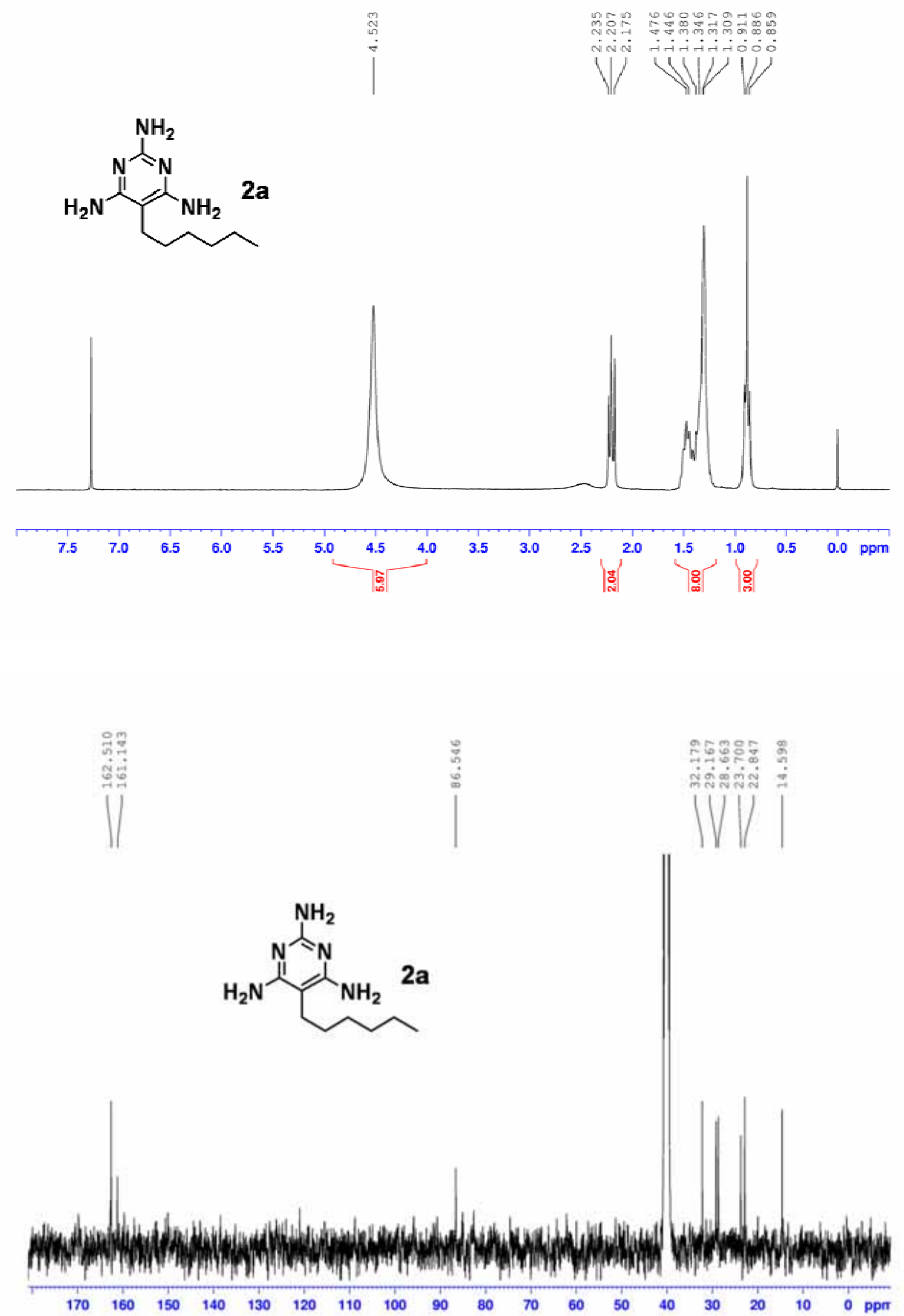



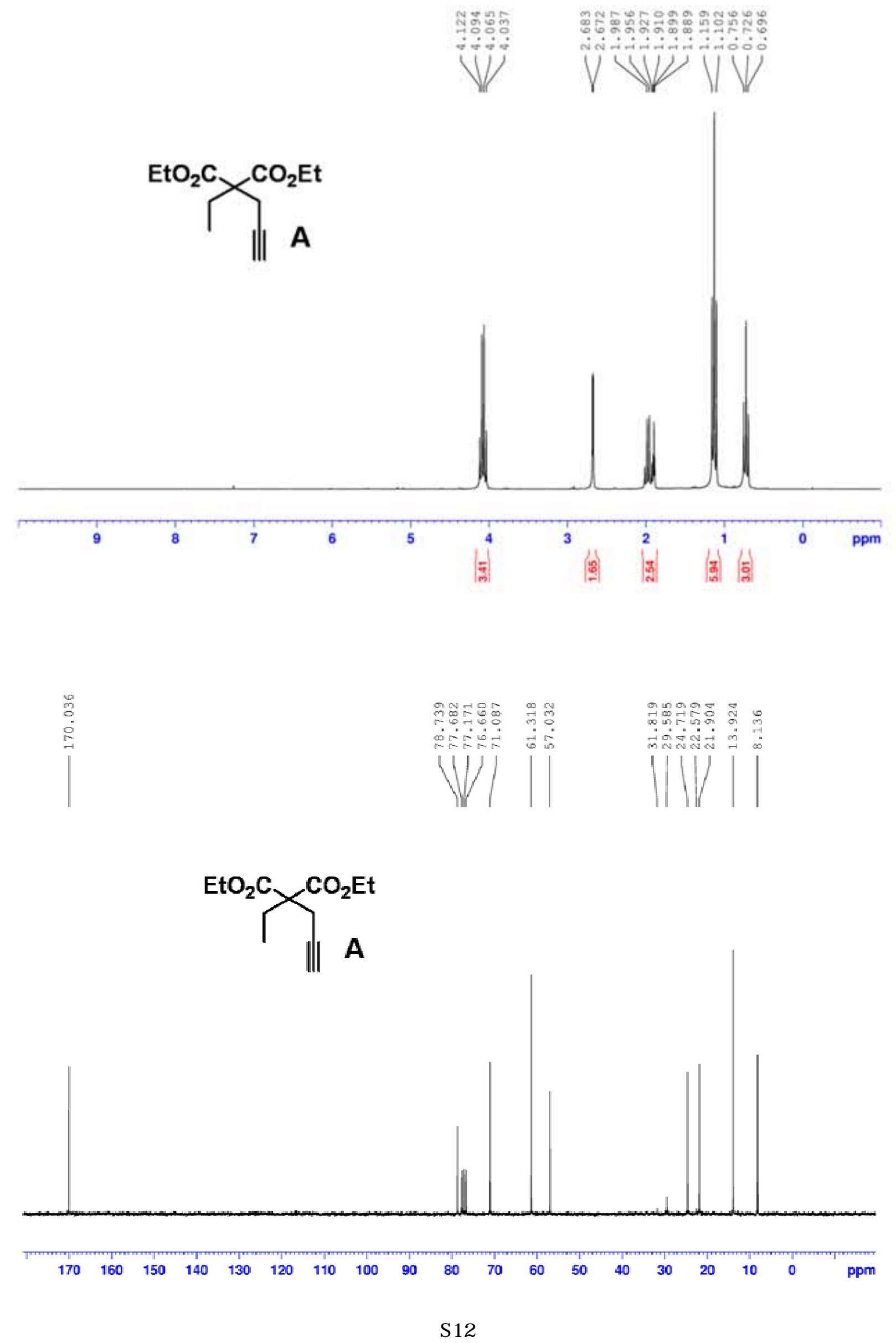


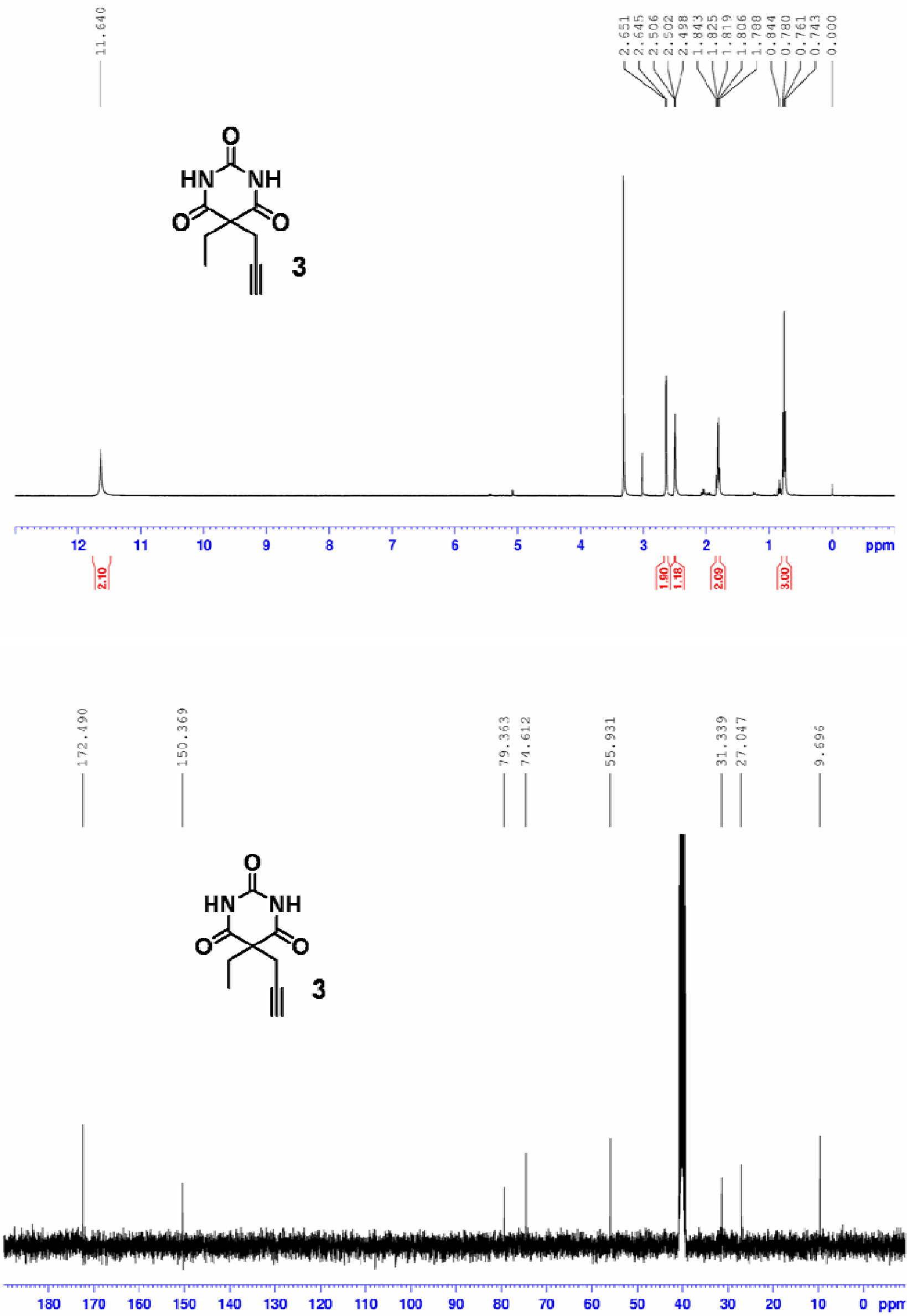



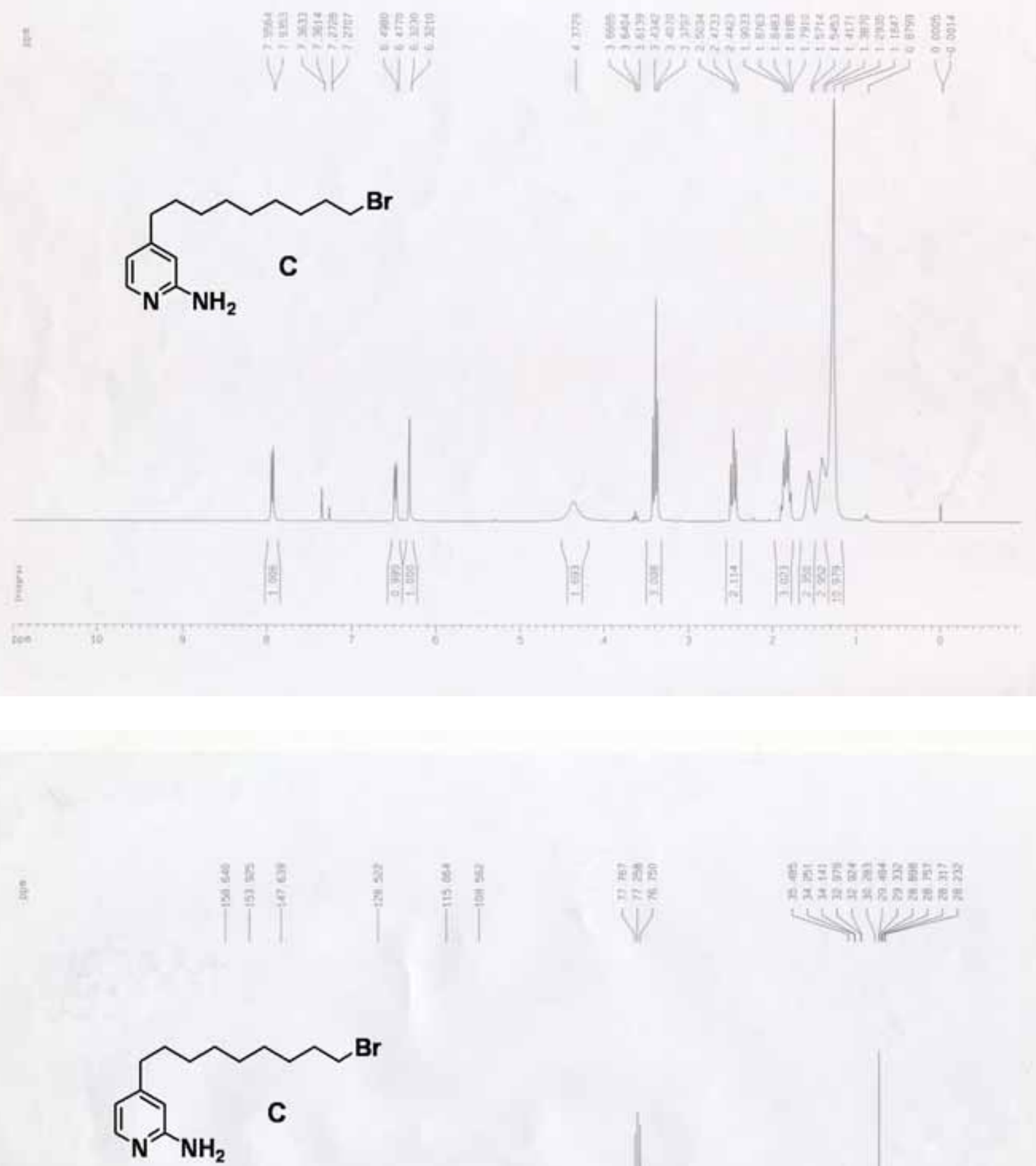


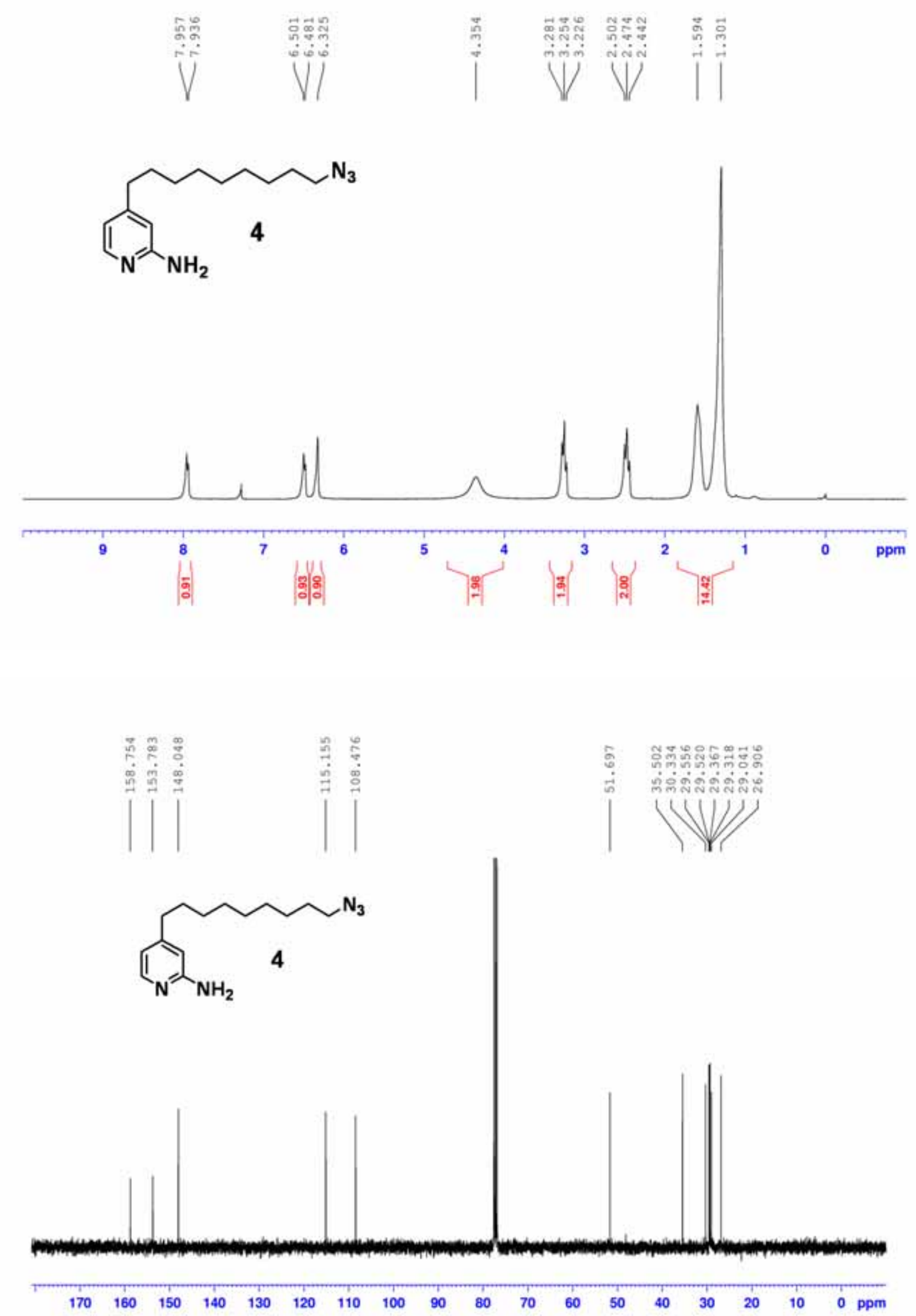



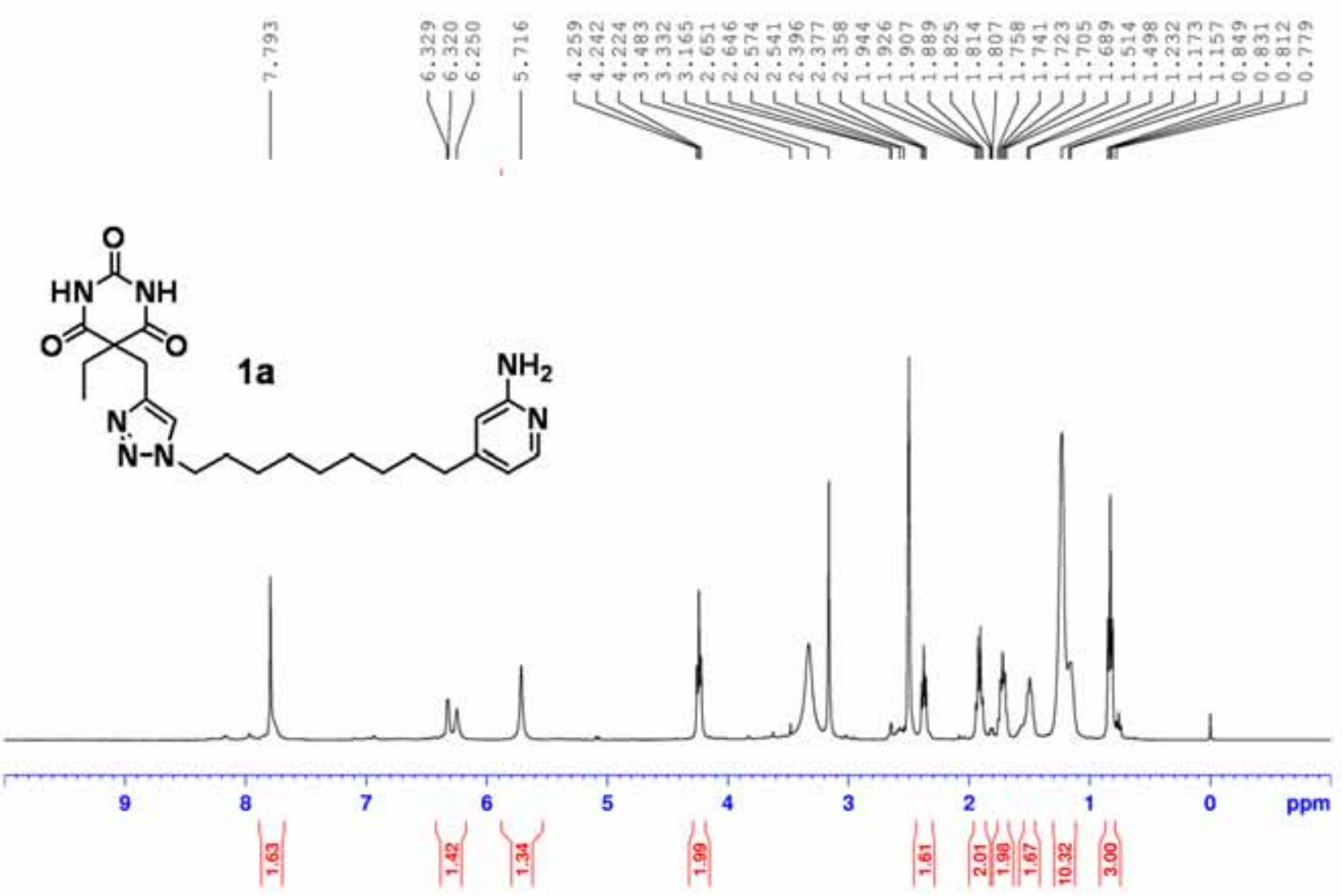

reference for $1 \mathbf{a}$

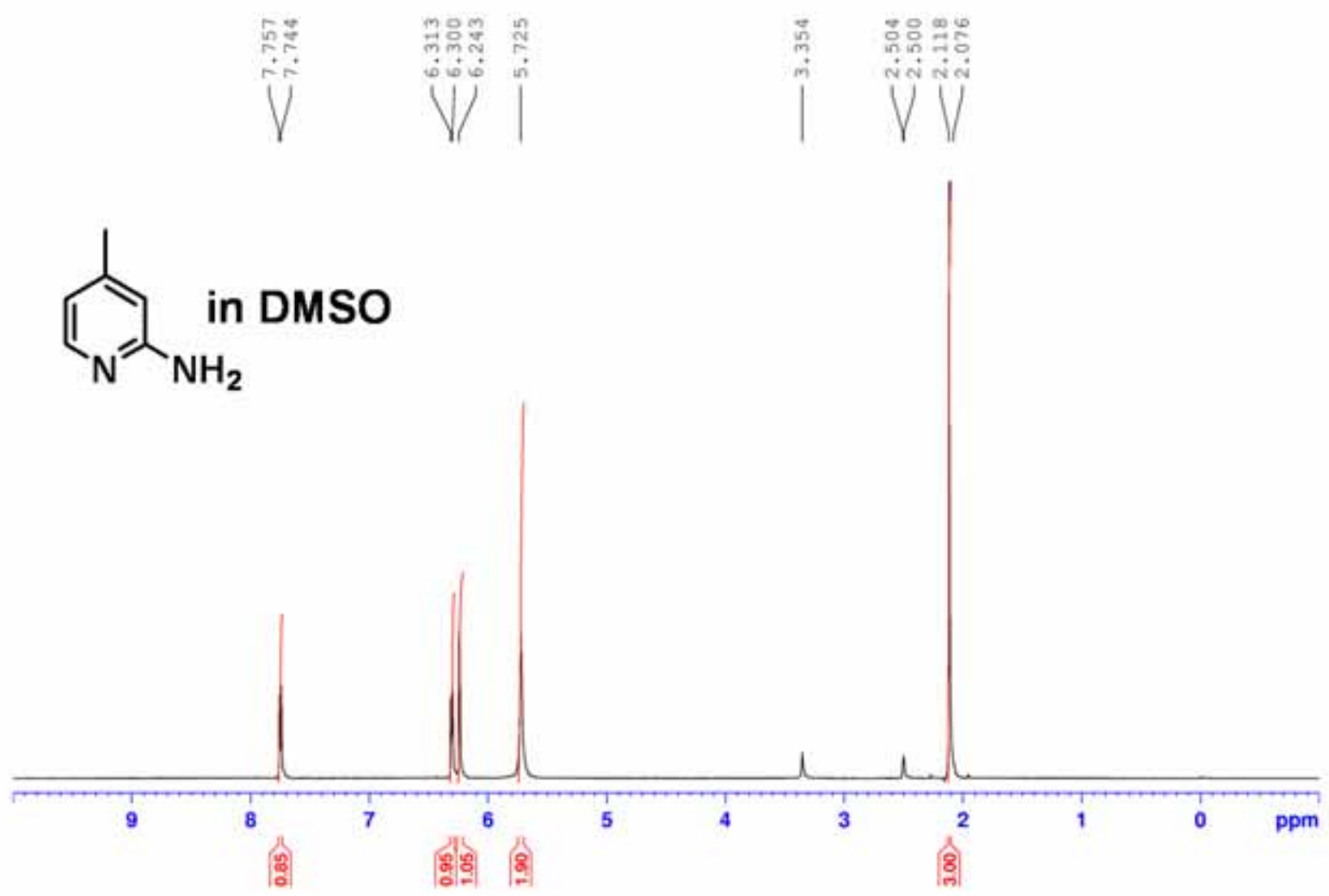



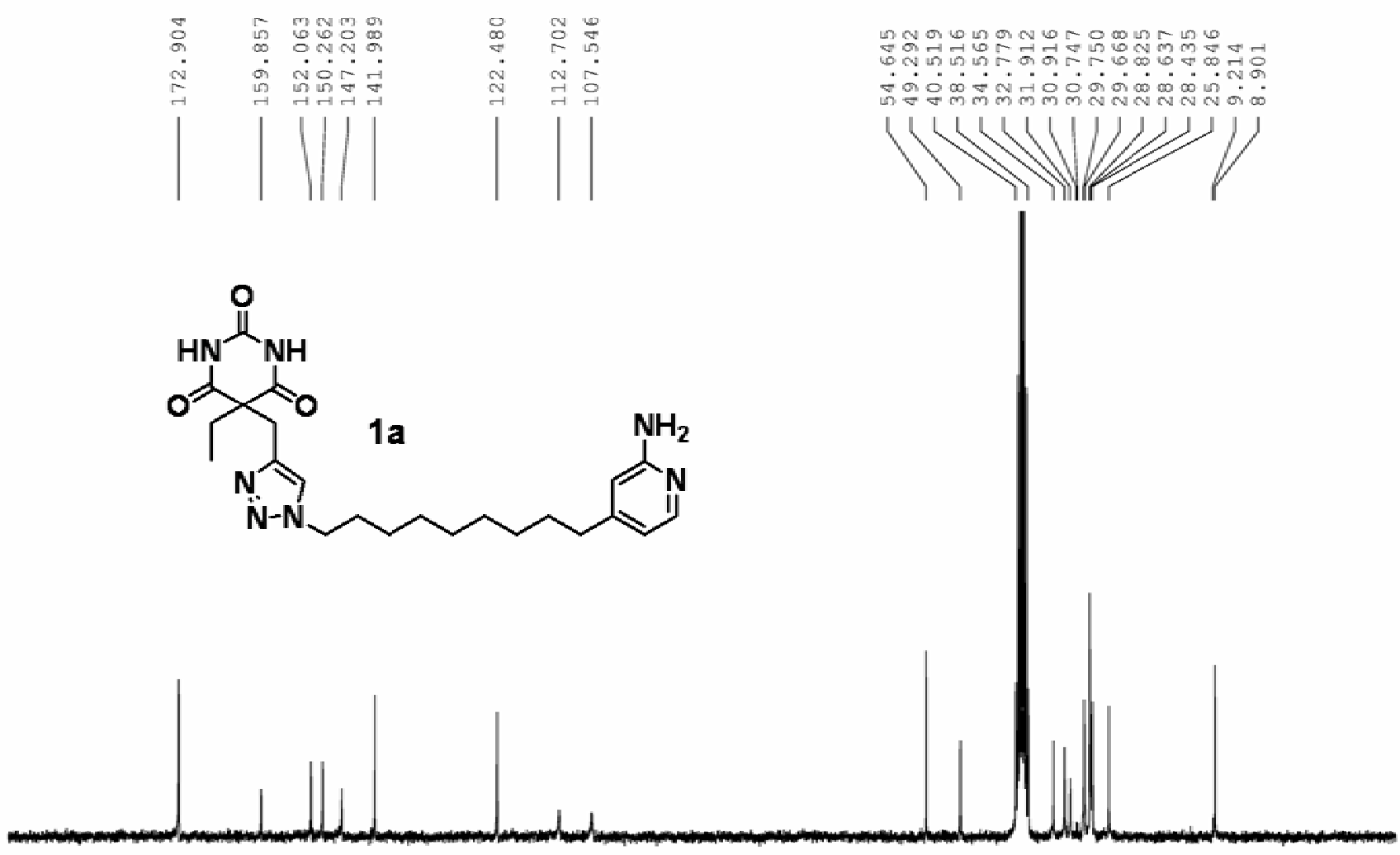

$\begin{array}{llllllllllllllllllllllll}190 & 180 & 170 & 160 & 150 & 140 & 130 & 120 & 110 & 100 & 90 & 80 & 70 & 60 & 50 & 40 & 30 & 20 & 10 & 0 & \text { ppm }\end{array}$ 


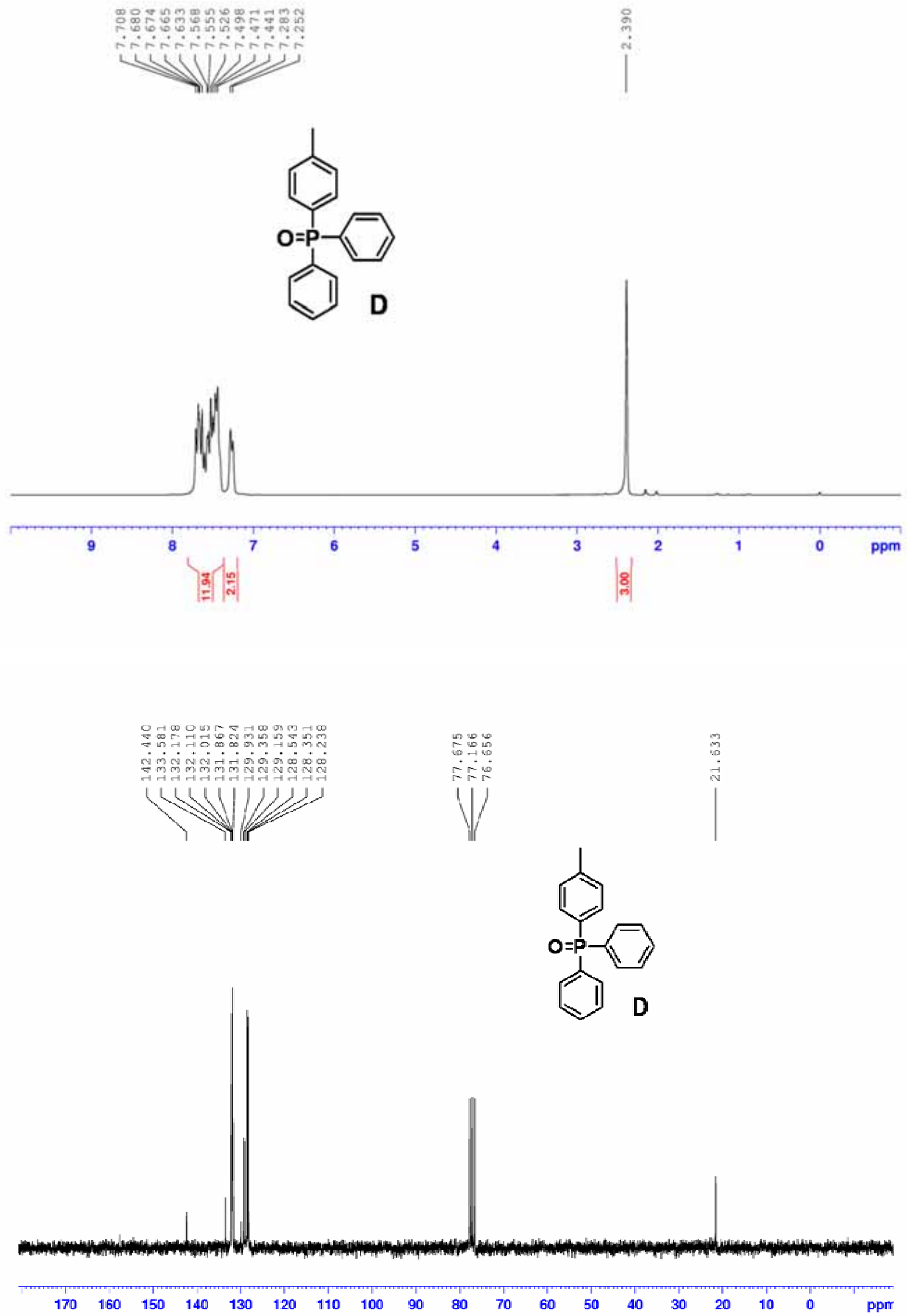



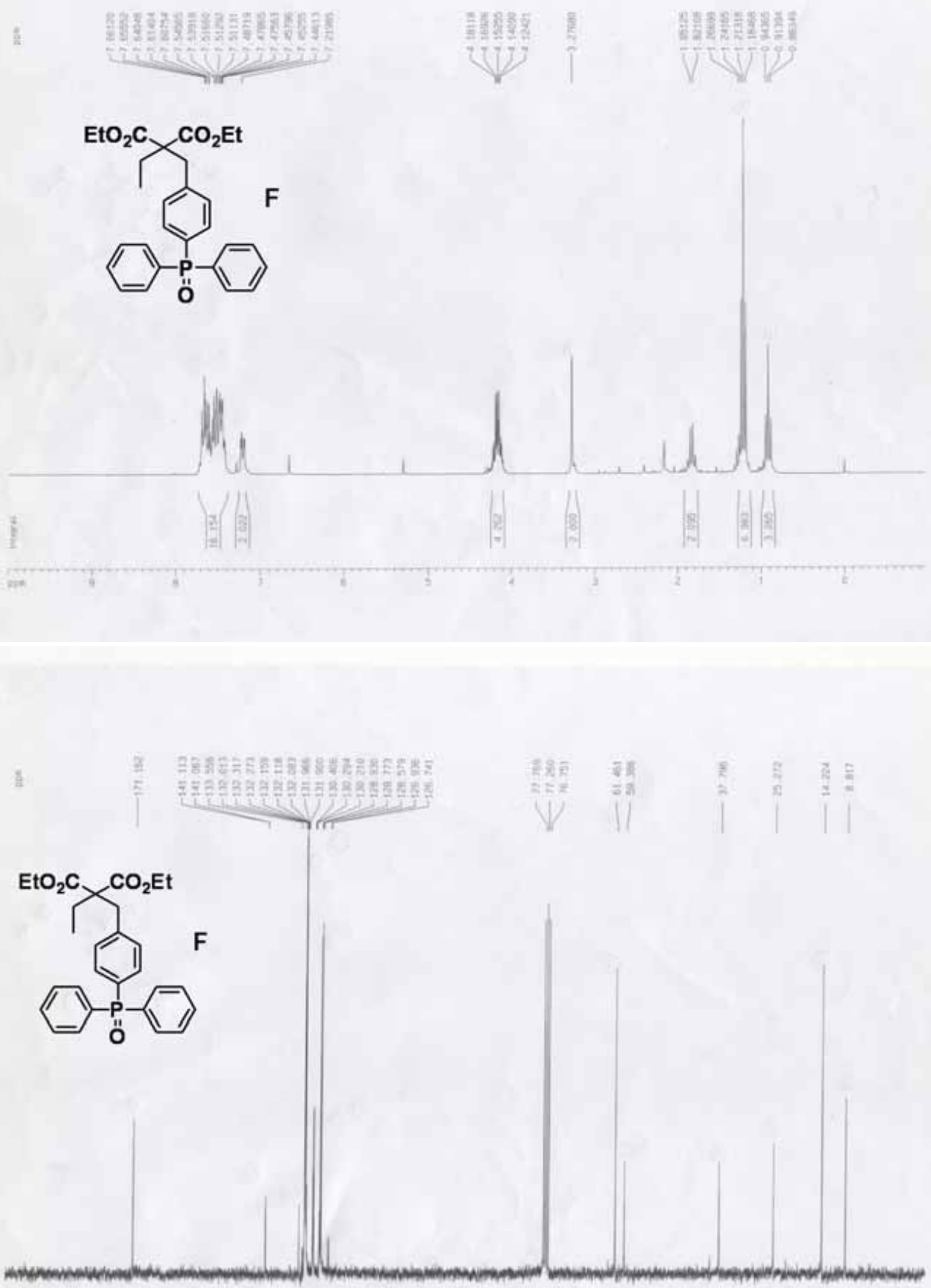

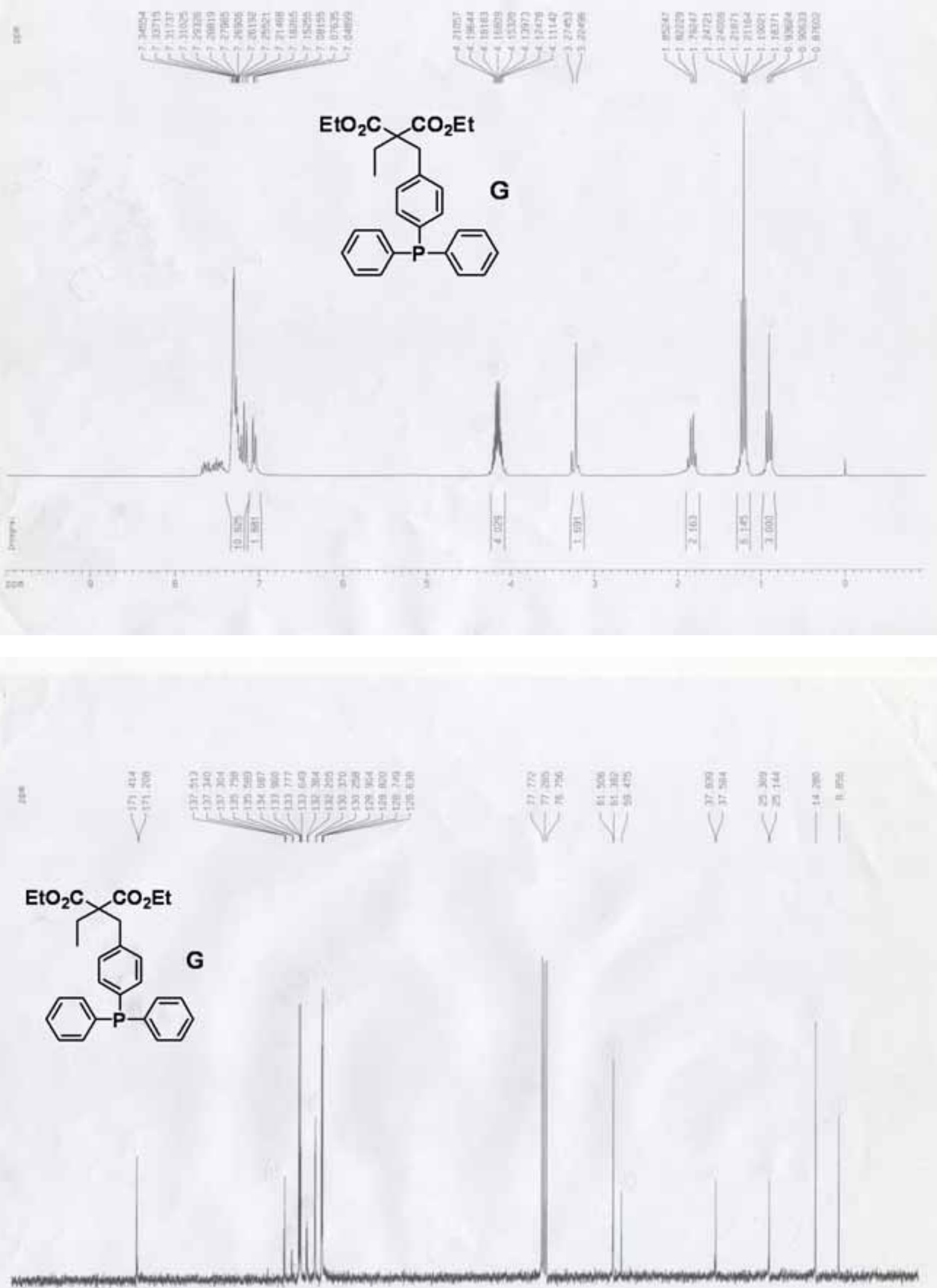

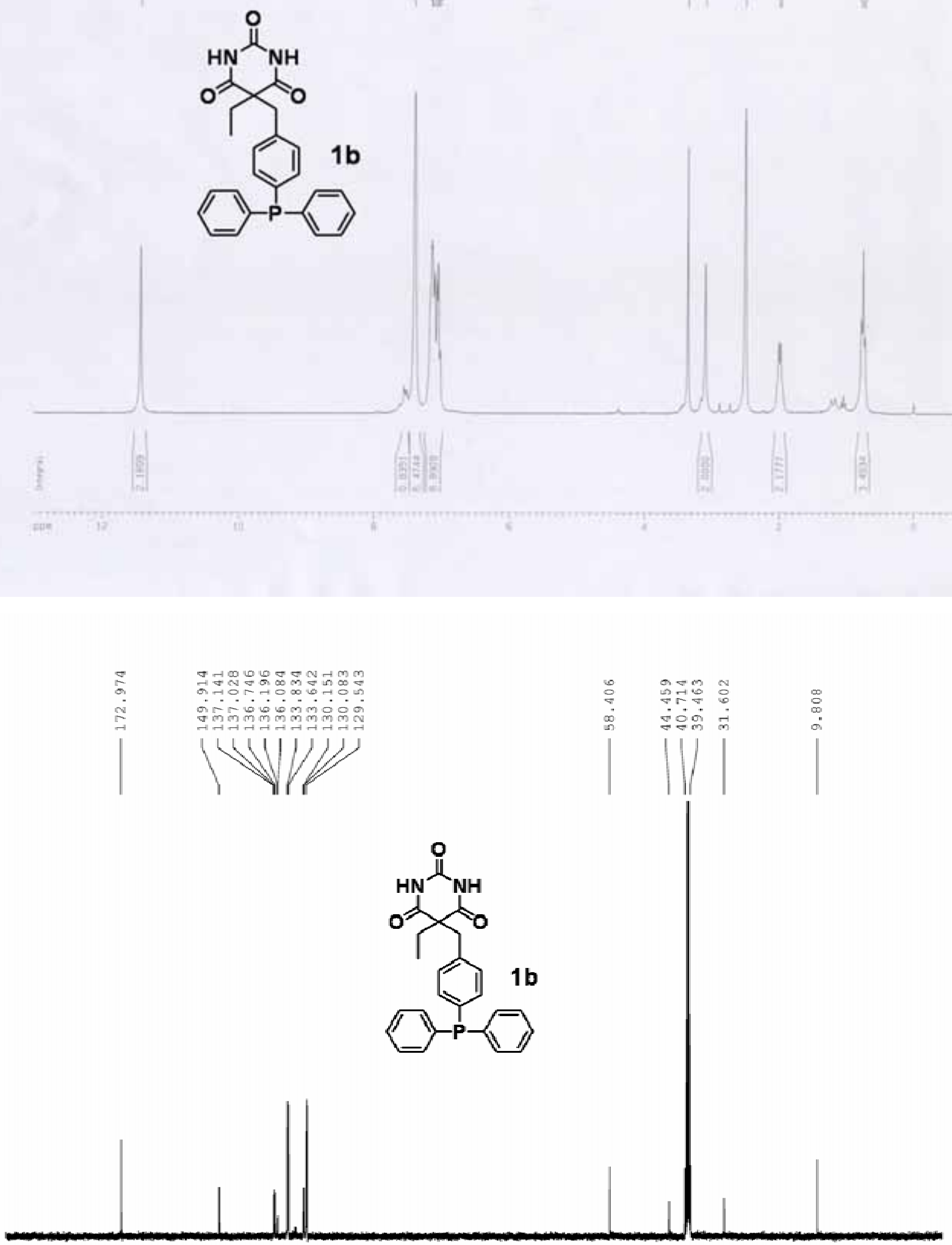

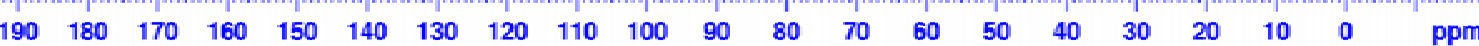

